following 1946-47, the non-university registrations reached a peak of 8,558 in 1949 , of whom 7,943 were part-time students, while in 1950 more than nine hundred students were attending post-advanced classes. According to a recent estimate, the extensions originally commenced in 1938 will almost double the present accommodation. Since 1924 the number of volumes and pamphlets in the library has increased from 12,000 to 33,500 , and the number of periodicals taken from 130 to 420 .

\section{Technical Education in the North of England}

A PAMPHLET entitled "Technical Education in the Northern Region", giving a summary list of courses which are available in the technical, commercial and art colleges and institutes of Cumberland, Durham, the North Riding of Yorkshire, Northumberland and Westmorland, has been issued by a subcommittee of the Northern Productivity Exhibition Planning Committee, organized by the Northern Regional Board for Industry in association with the Information Division of the Treasury and others. Since 1938-39 the number of full-time students in senior and advanced courses in the region has grown from 635 to 2,152 , of part-time day students from 909 to 10,552 and of evening students from 19,714 to 26,836 (1950-51), though part-time day release remains below the average for Great Britain as a whole. The Exhibition itself, which was held in the City Baths Hall, Newcastle upon Tyne, during October 30-November 6, 1952, included a technical college exhibit.

\section{German Hydrographic Institute, Hamburg : Report for 1951}

THE German Hydrographic Institute's report for 1951, its sixth yoar of activity (pp. $72+12 \mathrm{pl}$. ; from the Institute, Hamburg $11 ; 1952$ ), includes some retrospective statistics which go back to its foundation in 1946. On the whole, the Institute's work has been continued and progressively extended as in the years before, especially in the departments for nautical books and charts. Some events are mentioned which have a special importance for the Institute's further development. With regard to the work for the direct benefit of practical navigation, a committee has been established which includes representatives of all nautical and technical institutions, organizations and firms which are interested in the Institute's activities. This committee is to meet at suitable intervals in order to lodge requirements and make suggestions bearing upon the work of the Institute. As for the resumed participation in international scientific work, members of the Institute's staff took part in the meeting of the International Geophysical and Geodetic Union held in Brussels in August and September 1951, and in that of the International Council for the Exploration of the Sea held in Amsterdam in October 1951. Moreover, the Institute has been able to continue its research work in the North Sea from its vessel Gauss. In June 1951 a cruise was made in the Southern Bight of the North Sea for physical, chemical and plankton observations in association with contemporaneous British and Dutch fishery investigations, and a call was made at Lowestoft for discussions with British oceanographers there. During an autumn cruise in the German Bight and the Skagerrak, some methods and apparatus designed for practical marine seismology were tested, and several echograms of the deepest part of the Norwegian Trench were obtained. Following upon the Brussels and Amsterdam meetings referred to, the Institute was visited by many foreign scientific workers who had attended them.

Franklin's 'Philadelphia Experiment' on Lightning THE May 1952 number of the Journal of the Franklin Institute $(253$, No. 5) is devoted to the subject of lightning protection in commemoration of the two hundredth anniversary of the 'Philadelphia experiment' (May 10, 1752) on the identity of laboratory and thunderstorm electrification which was proposed by Benjamin Franklin. It contains a roproduction of the first photograph of lightning, believed to have been taken by W. N. Jennings on September 2, 1882, and four articles, by B. F. J. Schonland, I. B. Cohen, K. B. McEachron and H. Norinder, respectively. The first two deal with the historical background. Prof. Schonland gives an account of the experiments and hypotheses which led Franklin to propose the famous experiment and the lightning rod as a protective device, and Prof. Cohen describes the considerable prejudice which was aroused against the introduction of lightning rods. He quotes Prof. Schonland's conclusion from his recent book that "lightning still takes a considerable toll of unprotected property in the country from which the rod came", and points out that, although lightning was given the sixth place in importance among the causes of fire during 1921 by the United States National Board of Fire Underwriters, the number of buildings with adequate lightning protection is still but a small fraction of those that require rods. Dr. McEachron, of the General Electric Co., discusses lightning protection since Franklin's day, in particular with respect to communication systems, transportation and the electrical industry. Finally, Dr. Norrinder, of the Institutet för Högspanningsforskning, University of Uppsala, deals with experimental research into lightning discharges and effects in their vicinity. Meteorological aspects and the long-distance effects-atmospherics-are not considered. Optical methods, photographic methods and high-speed cathode-ray oscillograph methods of recording lightning discharges are described, and some of the results obtained, revealing the leader stroke mechanism, are discussed and illustrated.

\section{Handbook of the New Zealand Department of Scientific and Industrial Research}

The Department of Scientific and Industrial Research, New Zealand, has issued an illustrated and well-produced Departmental Handbook (pp. 68. Wellington : Govt. Printer, 1952) collecting much information previously only available from separate sources. An organization chart and brief account of the organization and administration of the Department is supplemented by some historical notes on its development and by maps indicating the geographical location of the units. The bulk of the Handbook consists of brief accounts of the functions and organization of the several divisions, laboratories, sections, etc., and of the incorporated research associations, including lists of staff. There is also a list of committees and their membership and of organizations in receipt of grants from the Department. The Handbook is completed with an index.

\section{New Light on Gnetales and Ephedrales}

Prof. A. J. Eames has considered in some detail, and in the light of modern knowledge, the relationships of that much-discussed plant group, the 